\title{
Cultivation of forage sorghum varieties irrigated with saline effluent from fish-farming under semiarid conditions
}

\author{
Miguel J. M. Guimarães ${ }^{1}$, Welson L. Simões ${ }^{2}$, José N. Tabosa ${ }^{3}$, José E. dos Santos ${ }^{4} \&$ Lilia Willadino $^{5}$ \\ ${ }^{1}$ Universidade Federal Rural de Pernambuco/Departamento de Engenharia Agrícola. Recife, PE. E-mail: mjmguimaraes@hotmail.com (Corresponding \\ author) \\ ${ }^{2}$ Embrapa Semiárido. Petrolina, PE. E-mail: welson.simoes@embrapa.br \\ ${ }^{3}$ Instituto Agronômico de Pernambuco. Recife, PE. E-mail: tabosa@ipa.br \\ ${ }^{4}$ Universidade de Pernambuco. Petrolina, PE. E-mail: josezequiel95@gmail.com \\ ${ }^{5}$ Universidade Federal Rural de Pernambuco/Departamento de Biologia. Recife, PE. E-mail: willadino.lilia@gmail.com
}

Key words:

leaching fraction

salinity

Sorghum bicolor (L.) Moench

\begin{abstract}
A B S T R A C T
This study aimed to evaluate the cultivation of forage sorghum subjected to different leaching fractions with saline effluent from fish-farming under semiarid conditions. The experiment was set in a randomized block design, with four blocks, in split plots, composed of four leaching fractions $(0 ; 5 ; 10$ and $15 \%)$ and three forage sorghum varieties ('Volumax', 'F305' and 'Sudão'). Irrigation was performed using saline effluent from fish farming with electrical conductivity of $2.5 \mathrm{dS} \mathrm{m}^{-1}$. The analyzed variables were: plant height; stem diameter; width, length and number of leaves; fresh and dry matter yield, and relative contents of potassium and sodium in the shoots. Forage sorghum under saline effluent irrigation and leaching fraction of $15 \%$ shows a yield increase of $25 \%$, in comparison to sorghum without the leaching fraction. The variety 'Volumax' was more sensitive to salinity than the others, since it showed lower shoot growth and low values of leaf area, fresh matter and dry matter.

\section{Cultivo de variedades de sorgo forrageiro irrigado com efluente salino da piscicultura em condições semiáridas}

\begin{abstract}
R E S U M O
O presente trabalho objetivou avaliar o cultivo de variedades de sorgo forrageiro submetido a diferentes frações de lixiviação com efluente salino da piscicultura em condições semiáridas. Foi adotado o delineamento experimental em blocos ao acaso, com quatro blocos, em parcelas subdivididas compostas por quatro frações de lixiviação (0; $5 ; 10$ e 15\%) nas parcelas e três variedades de sorgo forrageiro (Volumax, F305 e Sudão) nas subparcelas. A irrigação foi realizada com efluente salino da piscicultura (CE de 2,5 $\mathrm{dS} \mathrm{m}^{-1}$ ). As variáveis avaliadas foram altura da planta; diâmetro do colmo; largura, comprimento e número de folhas; produtividade de massa fresca e seca, além de teores de sódio e potássio na parte aérea. Observou-se que o sorgo forrageiro irrigado com efluente salino, com fração de lixiviação de $15 \%$ apresentou um aumento percentual de até $25 \%$ na produtividade quando comparada à do sorgo sem fração de lixiviação. A variedade Volumax mostrou-se mais sensível à salinidade que as demais em virtude de apresentar o menor crescimento da parte aérea e baixos valores de área foliar e matéria fresca e seca.
\end{abstract}




\section{INTRODUCTION}

The Brazilian semiarid region is characterized by low rainfall and high evaporative demand; hence, the multiple use of water is an important strategy for the sustainability of water resources. One alternative of subsistence for small cattle farmers in these regions, where the only source of water resources destined to irrigation is often a saline water table (Rebouças, 1999), is the use of integrated systems between agriculture and aquaculture.

In systems that use saline water for irrigation, the application of water depths that guarantee the leaching of part of the salts in the soil is fundamental to reduce salinity close to the plant root system. Thus, the challenge to obtain a good yield is the definition of an ideal water volume that guarantees such leaching and creates a comfortable environment for root development (Aragüésa et al., 2014).

Some studies conducted with forage and vegetable crops cultivated with water from fish- and shrimp-farming tanks, supplied with saline water, have shown promising results (Carvalho Júnior et al., 2010; Gurgel et al., 2012; Simões et al., 2016). Among these crops, sorghum shows great production potential for cultivation under saline water and is considered as moderately tolerant to salinity (Dias \& Blanco, 2010).

This crop stands out as a good forage for the Brazilian semiarid region for being typical of hot climate, with xerophytic characteristics, low demand in soil fertility, easy cultivation and fast establishment and growth, besides a good nutritional value and high forage production (Botelho et al., 2010; Gomes et al., 2006; Santos et al., 2013).

Therefore, the present study aimed to evaluate the cultivation of varieties of forage sorghum subjected to leaching fractions using saline fish-farming effluent under semiarid conditions.

\section{Material ANd Methods}

The experiment was conducted at the Caatinga Experimental Field of Embrapa Semi-arid, in Petrolina-PE, Brazil, in the region of the Submiddle São Francisco $\left(9^{\circ} 8^{\prime} 8.9^{\prime \prime}\right.$ S; $40^{\circ}$ $18^{\prime} 33.6^{\prime \prime}$ W; $373 \mathrm{~m}$ ), from February to July 2013. The soil in the experimental area was classified as Red Yellow Argisol (EMBRAPA, 2006), with medium texture and flat relief. The climate in the region is classified as semiarid, BSwh. During the experimental period, the relative air humidity was $63.86 \%$ and the temperature was around $25.46^{\circ} \mathrm{C}$. The maximum daily evapotranspiration observed was $6.97 \mathrm{~mm}$, with mean of 5.85 $\mathrm{mm} \mathrm{d}^{-1}$. The main rainfall events were concentrated in the first ten days after planting (DAP) and at 74 DAP, totaling $32.7 \mathrm{~mm}$ until the end of the cycle. The electrical conductivity of the irrigation water from fish-farming effluent showed a stable behavior, with mean of $2.5 \mathrm{dS} \mathrm{m}^{-1}$.

The experiment was set in a randomized block design, with four blocks, in split plots composed of three varieties of forage sorghum: 'Volumax', 'F305' and 'Sudão', and four leaching fractions (LF): 0, 0.05, 0.10 and 0.15, with saline fish-farming effluent; the leaching fractions corresponded to the plots and the varieties to the subplots. Each experimental unit (subplot) consisted of five $5-\mathrm{m}$-long rows, $0.5 \mathrm{~m}$ apart, with 10 plants per linear meter.

The experimental area was prepared according to the needs of the crop. Basal fertilization was performed based on the analysis of a previously collected soil sample (Table 1), applying $30 \mathrm{~kg} \mathrm{ha}^{-1}$ of nitrogen, $60 \mathrm{~kg} \mathrm{ha}^{-1}$ of phosphorus and $20 \mathrm{~kg} \mathrm{ha}^{-1}$ of potassium (Cavalcanti, 2008). At 30 DAP, a top-dressing nitrogen fertilization was performed using $30 \mathrm{~kg} \mathrm{ha}^{-1}$. Sowing was performed in April 2013 and emergence occurred at 7 DAP.

Irrigation was performed daily through a surface drip system, using drippers with flow rate of $1.6 \mathrm{~L} \mathrm{~h}^{-1}$, nominal diameter (ND) of $16 \mathrm{~mm}$ and spaced at $0.30 \mathrm{~m}$. Irrigation water came from $5-\mathrm{m}^{3}$ fish-farming tanks, containing black tilapia at a population density of 50 fish per cubic meter. In the management of the tanks, $50 \%$ of water was daily changed and destined to the irrigation of the experiment. The tanks were supplied with saline water from an artesian well $900 \mathrm{~m}$ distant from the experimental area, with electrical conductivity of $2.57 \mathrm{dS} \mathrm{m}^{-1}( \pm 0.2)$.

The chemical characteristics of the irrigation water from fish farming were determined in weekly evaluations during the experiment and the mean values are shown in Table 2.

The water depths applied through irrigation were calculated according to the crop evapotranspiration $\left(\mathrm{ETo}^{\star} \mathrm{Kc}{ }^{\star} \mathrm{Kl}\right)$, measured in the period between irrigations, based on the water application efficiency of the system and the tested leaching fractions, as in Eq. 1.

$$
\mathrm{Li}=\frac{(\mathrm{ETo} \cdot \mathrm{Kc} \cdot \mathrm{Kl})-\mathrm{P}}{\mathrm{Eff}} \cdot(1+\mathrm{LF})
$$

where:

$\mathrm{Li} \quad$ - irrigation depth, $\mathrm{mm}$;

ETo - evapotranspiration measured in the period, $\mathrm{mm}$;

Kc - crop coefficient;

Table 2. Chemical characteristics of the irrigation water from fish farming

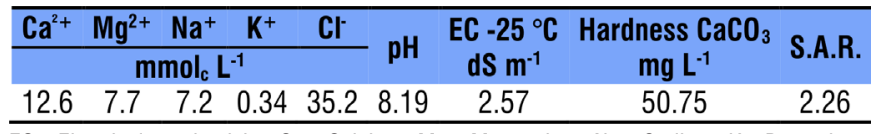

EC - Electrical conductivity; Ca - Calcium; Mg - Magnesium; Na - Sodium; K - Potassium; $\mathrm{Cl}^{-}$- Chloride; SAR - Sodium adsorption ratio

Table 1. Chemical, physical and granulometric parameters of the studied soil

\begin{tabular}{|c|c|c|c|c|c|c|c|c|c|c|c|c|c|c|c|c|c|c|c|c|}
\hline \multirow{2}{*}{$\begin{array}{l}\text { Layer } \\
\text { (cm) }\end{array}$} & \multirow{2}{*}{$\begin{array}{c}\text { EC } \\
d S \text { m }^{-1}\end{array}$} & \multirow[t]{2}{*}{$\mathrm{pH}$} & \multirow{2}{*}{$\underset{g^{~} \mathrm{~kg}^{-1}}{\mathrm{OM}}$} & \multirow{2}{*}{$\underset{\mathrm{mg} \mathrm{dm}}{P}$} & K & $\mathrm{Na}$ & $\mathrm{Ca}$ & $\mathrm{Mg}$ & Al & $\mathbf{H}+\mathbf{A l}$ & SB & CEC & \multirow{2}{*}{$\begin{array}{l}\mathbf{V} \\
\%\end{array}$} & \multicolumn{2}{|c|}{$\begin{array}{l}\text { Density } \\
\left(\mathrm{kg} \mathrm{dm}^{-3}\right)\end{array}$} & \multirow{2}{*}{$\begin{array}{c}\text { Total } \\
\text { porosity } \\
(\%)\end{array}$} & \multicolumn{3}{|c|}{$\begin{array}{c}\text { Granulometry } \\
\left(g^{~ k g}{ }^{-1}\right)\end{array}$} & \multirow{2}{*}{$\begin{array}{l}\begin{array}{l}\text { Moisture } \\
\left(\text { dag } \mathrm{kg}^{-1}\right)\end{array} \\
\text { FC PWP }\end{array}$} \\
\hline & & & & & \multicolumn{8}{|c|}{$\mathrm{cmol}_{\mathrm{c}} \mathrm{dm}^{-3}$} & & Bulk & Particle & & Sand & Silt & Clay & \\
\hline $0-10$ & 1.64 & 5.5 & 7.7 & 15.65 & 0.65 & 0.80 & 2.8 & 1.5 & 0 & 2. & 5.8 & 7.8 & 73.4 & 1.46 & 2.59 & 43.86 & 729.4 & 182.9 & 87.7 & 0.1860 .075 \\
\hline $10-20$ & 1.99 & 5.7 & 5.7 & 14.25 & 0.55 & 0.65 & 1.9 & 1.3 & 0 & 2.7 & 4.4 & 7.1 & 61.8 & 1.46 & 2.51 & 41 & 789.8 & 116.9 & 93.3 & 0.1790 .070 \\
\hline $20-45$ & 2.91 & 7.4 & 6.3 & 3.6 & 2.05 & 1.50 & 1.8 & 1.4 & 0 & 3.7 & 6.8 & 10.4 & 64.7 & 1.37 & 2.52 & 45.58 & 613.2 & 178.1 & 208.7 & 0.1810 .110 \\
\hline
\end{tabular}

EC - Electrical conductivity of the saturation extract; OM - Organic matter; P - Available phosphorus extracted with Mehlich-1; Ca - Exchangeable calcium; Mg - Exchangeable magnesium; Na Exchangeable sodium; K - Exchangeable potassium; Al - Exchangeable acidity; CEC - Cation exchange capacity at pH 7.0; V - Base saturation; FC - Field capacity; PWP - Permanent wilting point 
$\mathrm{Kl}$ - location coefficient;

$\mathrm{P} \quad$ - rainfall measured in the period, $\mathrm{mm}$;

Eff - irrigation system efficiency, 0.9; and,

LF - applied leaching fraction, decimal.

Harvest was performed in July, when the organs of the central portion of the panicle showed a pasty-to-farinaceous aspect. At harvest, soil samples were collected in the wet strip in the layers of $0-5,5-20,20-40,40-60$ and $60-80 \mathrm{~cm}$ for the determination of electrical conductivity, using the saturation paste extract of each layer. The plants of each plot were cut at a height of $10 \mathrm{~cm}$ from the soil and the following parameters were evaluated: fresh matter, number of leaves, length and width of the +3 leaf; plant height and stem diameter. Then, the material was dried in an oven at $60^{\circ} \mathrm{C}$ until constant weight, for the determination of dry matter.

Leaf blade samples were ground in a knife mill and subjected to nitric-perchloric digestion for the determination of $\mathrm{Na}^{+}$and $\mathrm{K}^{+}$through flame photometry (Malavolta et al., 1997).

The obtained data were subjected to analysis of variance (ANOVA) using the program Sisvar 5.0. First- and seconddegree regression models were used for the comparison between leaching fractions, when significant at 0.01 or 0.05 probability level. Tukey test at 0.05 probability level was adopted for the comparison between the varieties.

\section{Results AND Discussion}

The highest leaching fractions promoted lower values of electrical conductivity of the saturation extract (ECe) in the soil profile, gradually reducing the concentration of salts as the leaching fractions increased. This fact corroborates the results of Simões et. al. (2016), who irrigated beet also with saline fish-farming effluent. This is due to displacement of salts in the wet bulb through mass flow. The highest concentrations of salts were observed in the layer of $0-5 \mathrm{~cm}$, with ECe values of 10.34 and $11.6 \mathrm{dS} \mathrm{m}^{-1}$ for the leaching fractions of 5 and $0 \%$, respectively (Table 3 ).

Table 3. Mean electrical conductivity of the saturation extract (ECe) of the soil cultivated with forage sorghum varieties subjected to leaching fractions of $0,5,10$ and $15 \%$

\begin{tabular}{ccccc}
\hline \multirow{2}{*}{ Layer $(\mathbf{c m})$} & \multicolumn{4}{c}{ Leaching fraction } \\
\cline { 2 - 5 } & $\mathbf{0}$ & $\mathbf{0 . 0 5}$ & $\mathbf{0 . 1 0}$ & $\mathbf{0 . 1 5}$ \\
$0-5$ & 11.60 & 10.34 & 5.77 & 3.03 \\
$5-20$ & 5.54 & 3.90 & 3.37 & 2.98 \\
$20-40$ & 5.41 & 4.01 & 3.50 & 2.94 \\
$40-60$ & 5.28 & 4.21 & 3.60 & 3.17 \\
$60-80$ & 4.59 & 5.97 & 3.03 & 3.33 \\
Mean & 6.48 & 5.68 & 3.85 & 3.09 \\
\hline
\end{tabular}

Higher values of electrical conductivity in the upper soil layers were also observed in the cultivation of beet (Ferreira et al., 2006; Simões et al., 2016) and peanut (Santos et al., 2012) subjected to leaching fractions with saline water.

Considering that approximately $80 \%$ of the effective root system of sorghum is found in the soil layer of $0-30 \mathrm{~cm}$ (Magalhães et al., 2000), the 0.15 leaching fraction resulted in greater reduction of salts in this layer and its electrical conductivity was lower than $4.0 \mathrm{dS} \mathrm{m}^{-1}$. Since this ECe value is adopted as a limit, to avoid the general negative effects on plant development (Dias \& Blanco, 2010), it is evident the viability of sorghum cultivation using water of $2.57 \mathrm{dS} \mathrm{m}^{-1}$ along with the application of a leaching fraction of 0.15 .

There was no significant interaction between the varieties and the applied leaching fractions with respect to plant height. The varieties 'Sudão' and 'F305' showed greater values of plant height compared with 'Volumax', and the variety 'F305' showed higher number of leaves (Table 4). There was no significant difference for stem diameter ( $\varnothing$ ) between the studied varieties. As to plant biometry, the leaves of 'Sudão' sorghum were longer, but narrower, in comparison to 'Volumax' and 'F305'.

The variety 'Sudão' showed the highest fresh matter yield, significantly differing from 'Volumax'. For dry matter, the variety 'F305' showed the highest and 'Volumax' the lowest yields (Table 4). 'Volumax', in different environments and under irrigation with non-saline water, showed mean dry matter yields from 6.8 to $10.54 \mathrm{t} \mathrm{ha}^{-1}$ (Avelino et al., 2011; Gomes et al., 2006) and the variety 'F305' showed dry matter yield of 9.77 $\mathrm{t} \mathrm{ha}^{-1}$, also in a non-saline environment (Moraes et al., 2013).

The reduction in dry matter yield due to the application of leaching fractions was expected, since it is a typical response of plants to saline stress, resulting from the decrease in soil osmotic potential and the toxic effects of the accumulation of $\mathrm{Na}^{+}$and $\mathrm{Cl}^{+}$, which promote physiological disorders in the plant.

Reduction in sorghum yield due to salinity has been reported in various studies and its magnitude depends on ECe, edaphoclimatic conditions etc. The variety 'Volumax',

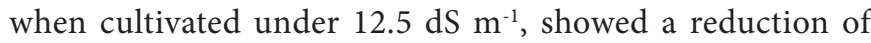
more than $40 \%$ in the accumulation of fresh and dry matter (Coelho et al., 2014); the variety 'Sudão' subjected to $100 \mathrm{mM}$ with $\mathrm{NaCl}$, in a greenhouse, showed reduction of $60 \%$ in dry matter production (Feijão et al., 2011) and the genotypes CSF 18 and CSF 20 showed reductions of 23 and $8 \%$, respectively, when subjected to $5.8 \mathrm{dS} \mathrm{m}^{-1}$ under field conditions, which represent estimated decreases of 0.34 and $0.12 \mathrm{~kg}$ of dry matter per square meter (Vieira et al., 2005). The tolerance index of the shoots in two forage sorghum genotypes subjected to electrical conductivity of $6.0 \mathrm{dS} \mathrm{m} \mathrm{m}^{-1}$ showed a reduction from 29 to $40 \%$ (Aquino et al., 2007).

Table 4. Comparison between forage sorghum varieties for the growth variables: plant height, stem diameter, number of live leaves, length and width of the +3 leaf, total leaf area (TLA) and yield

\begin{tabular}{|c|c|c|c|c|c|c|c|c|}
\hline \multirow{2}{*}{ Variety } & \multirow{2}{*}{$\begin{array}{l}\text { PH } \\
\text { (cm) }\end{array}$} & \multirow{2}{*}{$\begin{array}{c}\emptyset \\
(\mathrm{mm})\end{array}$} & \multirow{2}{*}{ NL } & \multicolumn{2}{|c|}{+3 Leaf $(\mathrm{cm})$} & \multirow{2}{*}{$\begin{array}{c}\text { TLA } \\
\left(\mathrm{cm}^{2}\right)\end{array}$} & \multicolumn{2}{|c|}{ Yield $\left(\mathrm{t} \mathrm{ha} \mathrm{a}^{-1}\right)$} \\
\hline & & & & Length & Width & & FM & DM \\
\hline 'Volumax' & $139.4 \mathrm{~b}$ & $13.1 \mathrm{a}$ & $7.2 \mathrm{~b}$ & $36.9 \mathrm{~b}$ & $4.2 \mathrm{a}$ & $770.5 \mathrm{~b}$ & $22.71 \mathrm{~b}$ & $6.99 \mathrm{~b}$ \\
\hline 'F305' & $155.8 \mathrm{a}$ & $13.8 \mathrm{a}$ & $9.2 \mathrm{a}$ & $39.4 \mathrm{~b}$ & $4.5 \mathrm{a}$ & $1155.8 \mathrm{a}$ & $25.45 a b$ & $8.97 \mathrm{a}$ \\
\hline 'Sudão' & $155.8 \mathrm{a}$ & $13.3 \mathrm{a}$ & $7.0 \mathrm{~b}$ & $49.3 \mathrm{a}$ & $3.9 \mathrm{~b}$ & $950.3 \mathrm{ab}$ & $27.79 \mathrm{a}$ & $8.01 \mathrm{ab}$ \\
\hline
\end{tabular}

PH - Plant height; $\varnothing$ - Stem diameter; NL - Number of live leaves; TLA - Total leaf area; FM - Fresh matter; DM - Dry matter

Same letters in the same column do not differ by Tukey test at 0.05 probability level 
The increment of leaching fractions promoted a directly proportional increase in plant height, stem diameter and fresh and dry matter yields of sorghum plants. Such behavior was best represented by first-degree equations (Figure 1).

Fresh and dry matter yields of the forage sorghum varieties showed maximum of 27.51 and $9.09 \mathrm{tha}^{-1}$, respectively, when a leaching fraction of $15 \%$ was applied, which corresponds to an increment of approximately 25\% (Figure 1). The increase in yield due to the application of leaching fractions with saline water was also observed in cowpea (Assis Júnior et al., 2007), peanut (Santos et al., 2012) and beet (Simões et al., 2016). On the other hand, it is important to note that high leaching fractions may cause reduction in crop yield, for reducing the concentration of both potentially toxic ions and ions indispensable for plant mineral nutrition, as observed in the weight of corn grains grown under irrigation with saline water $\left(3.3 \mathrm{dS} \mathrm{m}^{-1}\right)$ and leaching fraction of $20 \%$ (Carvalho et al., 2012).

As to sodium $\left(\mathrm{Na}^{+}\right)$content, there was a parabolic behavior for the three varieties (Table 5). The varieties 'Volumax' and 'F305' showed increase in $\mathrm{Na}^{+}$contents, with maximum values in plants subjected to 0.05 leaching fraction, while 'Sudão' showed higher $\mathrm{Na}^{+}$content when a 0.15 leaching fraction was applied.

In general, there were lower contents of potassium $\left(\mathrm{K}^{+}\right)$ at the highest leaching fractions (Table 5), due to the greater leaching of salts in the soil, as expected. The variety 'Sudão' showed the highest $\mathrm{K}^{+}$content at the leaching fraction of $15 \%$ $\left(9.88 \mathrm{~g} \mathrm{~kg}^{-1}\right)$, while the others showed a value of approximately $5.5 \mathrm{~g} \mathrm{~kg}^{-1}$, which evidences the deficiency of this element (Coelho et al., 2002). It should be pointed out that, with the leaching fraction of 0.15 , all genotypes obtained the highest fresh and dry matter yields, as well as the lowest soil electrical conductivity (ECe). At this same leaching fraction, the highest content of $\mathrm{Na}^{+}$occurred in the variety 'Sudão' and it was almost twice that of the others.

Considering that the variety 'Sudão' stands out for the highest fresh matter yield and for being in the group of highest dry matter yield and leaf area, its higher capacity of acclimation is evident. This behavior suggests its ability to compartmentalize the $\mathrm{Na}^{+}$present in the leaf blade, whether in the vacuole or in the apoplast, avoiding its accumulation in the cytoplasm and organelles, which would result in metabolic disorders and, consequently, reduction in crop performance (Plett \& Moller, 2010).
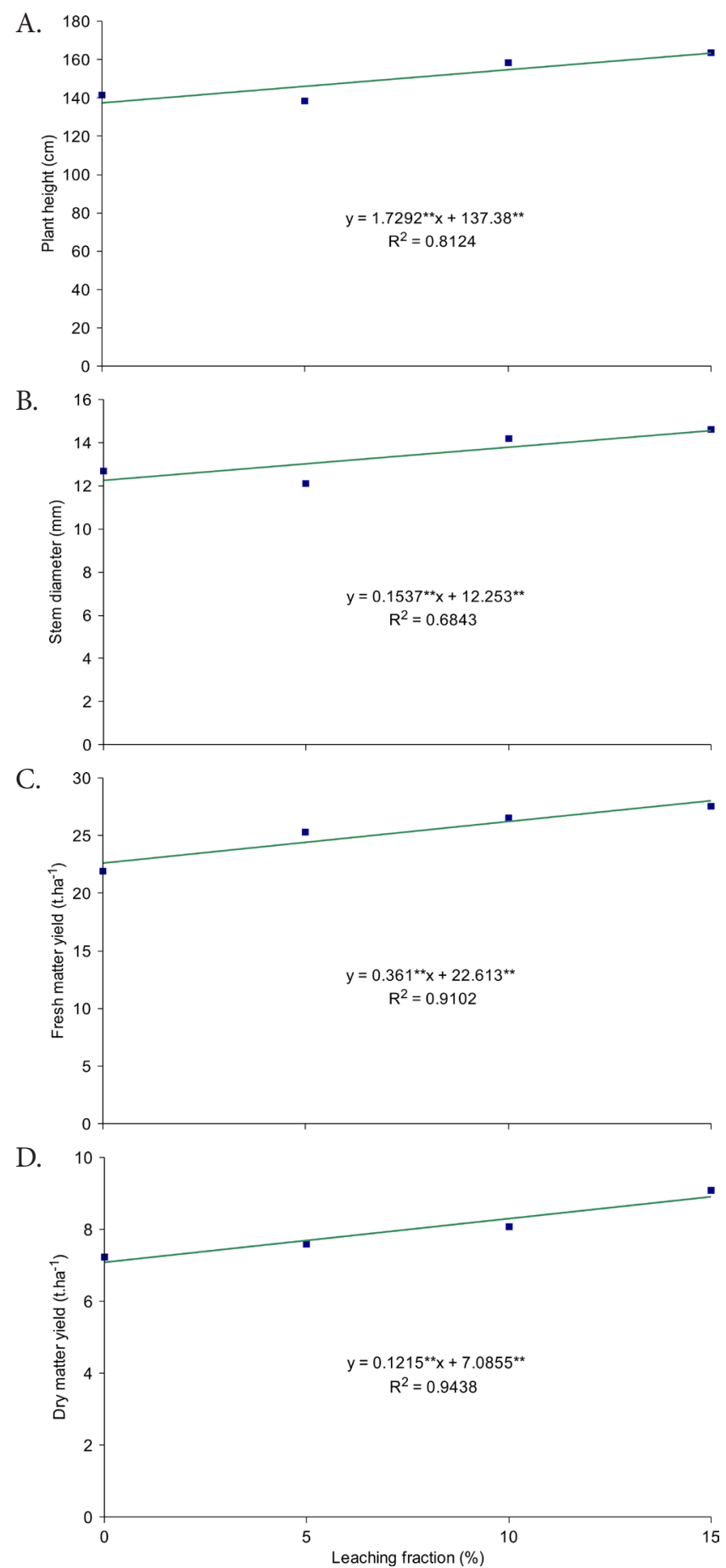

Figure 1. Plant height (A), stem diameter (B), fresh matter yield (C) and dry matter yield (D) of forage sorghum varieties subjected to different leaching fractions with saline water from fish farming

Table 5. Leaf contents of potassium $(\mathrm{K})$ and sodium $(\mathrm{Na})$ in varieties of forage sorghum subjected to leaching fractions with saline fish-farming effluent under semiarid conditions

\begin{tabular}{|c|c|c|c|c|c|c|}
\hline \multirow{2}{*}{ Variety } & \multicolumn{4}{|c|}{ Leaching fraction } & \multirow{2}{*}{ Regression equation } & \multirow[b]{2}{*}{$\mathbf{R}^{2}$} \\
\hline & 0 & 0.05 & 0.10 & 0.15 & & \\
\hline \multicolumn{7}{|c|}{$K\left(\mathrm{~g} \mathrm{~kg}^{-1}\right)$} \\
\hline 'Volumax' & $8.91 \mathrm{~b}$ & $11.61 \mathrm{~b}$ & $10.21 \mathrm{a}$ & $5.44 \mathrm{~b}$ & $y=-0.075^{\star \star} x^{2}+0.886^{\star \star} x+8.943^{\star \star}$ & 0.99 \\
\hline 'F305' & $8.19 b$ & $10.86 b$ & $7.03 \mathrm{~b}$ & $5.52 b$ & $y=-0.236^{* *} x+9.673^{* *}$ & 0.46 \\
\hline 'Sudão' & $15.65 \mathrm{a}$ & $17.12 \mathrm{a}$ & $7.36 \mathrm{~b}$ & $9.88 \mathrm{a}$ & $y=-0.541^{\star \star} x+16.561^{\star \star}$ & 0.56 \\
\hline \multicolumn{7}{|c|}{$\mathrm{Na}\left(\mathrm{mg} \mathrm{kg}^{-1}\right)$} \\
\hline 'Volumax' & $220.58 \mathrm{~b}$ & $262.90 \mathrm{ab}$ & $275.24 \mathrm{a}$ & $248.79 \mathrm{~b}$ & $y=-0.68^{\star *} x^{2}+12.25^{\star \star} x+22.14^{\star *}$ & 0.99 \\
\hline 'F305' & $177.38 \mathrm{~b}$ & $245.26 b$ & $244.56 \mathrm{a}$ & 199.42 b & $y=-1.13^{\star \star} x^{2}+18.26^{\star \star} x+178.58^{\star \star}$ & 0.99 \\
\hline 'Sudão' & $329.90 \mathrm{a}$ & $314.92 \mathrm{a}$ & $272.29 \mathrm{a}$ & $505.36 \mathrm{a}$ & $y=2.48^{\star} x^{2}-27.534^{\star \star} x+345.07^{\star *}$ & 0.85 \\
\hline
\end{tabular}

Same letters in the same column do not differ by Tukey test at 0.05 probability level. ${ }^{* \star}$, ${ }^{\star}$ Coefficient of regression significant at 0.01 and 0.05 probability levels, respectively 


\section{Conclusions}

1. It is viable to cultivate forage sorghum in the Brazilian semiarid region under irrigation with saline water from fishfarming tanks, with mean electrical conductivity of $2.57 \mathrm{dS} \mathrm{m}^{-1}$, and application of a leaching fraction of 0.15 .

2. The variety 'Volumax' is more sensitive to salinity in comparison to 'F305' and 'Sudão', since it showed lower shoot growth and low values of leaf area, fresh matter and dry matter.

\section{Literature Cited}

Aquino, A. J. S.; Lacerda, C. F. de; Gomes Filho, E. Crescimento, partição de matéria seca e retenção de $\mathrm{Na}^{+}, \mathrm{K}^{+}$e $\mathrm{Cl}^{-}$em dois genótipos de sorgo irrigados com águas salinas. Revista Brasileira de Ciência do Solo, v.31, p.961-971, 2007. http://dx.doi. org/10.1590/S0100-06832007000500013

Aragüésa, R.; Medina, E. T.; Clavería, I.; Martínez-Cobb, A.; Faci, J. Regulated deficit irrigation, soil salinization and soil sodification in a table grape vineyard drip-irrigated with moderately saline waters. Agricultural Water Management. v.134, p.84-93, 2014. http://dx.doi.org/10.1016/j.agwat.2013.11.019

Assis Júnior, J. O.; Lacerda, C. F. de; Silva, C. F.; Silva, F. L. B.; Bezerra, M. A.; Gheyi, H. R. Produtividade do feijão-de-corda e acúmulo de sais no solo em Função da fração de lixiviação e da salinidade da água de Irrigação. Engenharia Agrícola, v.27, p.702-713, 2007. http://dx.doi.org/10.1590/S0100-69162007000400013

Avelino, P. M.; Neiva, J. N. M.; Araújo, V. L.; Alexandrino, E.; Santos, A. C.; Restle, J. Características agronômicas e estruturais de híbridos de sorgo em função de diferentes densidades de plantio. Revista Ciência Agronômica, v.42, p.534-541, 2011. http://dx.doi. org/10.1590/S1806-66902011000200037

Botelho, P. R. F.; Pires, D. A. A.; Sales, E. C. J.; Rocha Júnior, V. R.; Reis, S. T. Avaliação de genótipos de sorgo em primeiro corte e rebrota para produção de silagem. Revista Brasileira de Milho e Sorgo, v.9, p.287-297, 2010. http://dx.doi.org/10.18512/19806477/rbms.v9n3p287-297

Carvalho, J. F. de; Tsimpho, C. J.; Silva, E. F. de F. e; Medeiros, P. R. F. de; Santos, M. H. V. dos; Santos, A. N. dos. Produção e biometria do milho verde irrigado com água salina sob frações de lixiviação. Revista Brasileira de Engenharia Agrícola e Ambiental, v.16, p.368-374, 2012. http://dx.doi.org/10.1590/ S1415-43662012000400006

Carvalho Júnior, S. B. de; Furtado, D. A.; Silva, V. R. da; Dantas, R. T.; Lima, I. S. P.; Lima, V. L. A. de. Produção e avaliação bromatológica de espécies forrageiras irrigadas com água salina. Revista Brasileira de Engenharia Agrícola e Ambiental, v.14, p.1045-1051, 2010. http://dx.doi.org/10.1590/S1415-43662010001000004

Cavalcanti, F. J. de A. Recomendações de adubação para o estado de Pernambuco. 2a Apr. 3.ed., Recife: IPA, 2008. 212p.

Coelho, A. M.; Waquil, J. M.; Karam, D.; Casela, C. R.; Ribas, P. M. Seja o doutor do seu sorgo. Informações Agronômicas, n.100, p.1-12, 2002.

Coelho, D. S.; Simões, W. L.; Mendes, A. M. S.; Dantas, B. F.; Rodrigues, J. A. S.; Souza, M. A. Germinação e crescimento inicial de variedades de sorgo forrageiro submetidas ao estresse salino. Revista Brasileira de Engenharia Agrícola e Ambiental, v.18, p.2530, 2014. http://dx.doi.org/10.1590/S1415-43662014000100004
Dias, N. da S.; Blanco, F. F. Efeitos dos sais no solo e na planta. In: Gheyi, H. R.; Dias, N. da S.; Lacerda, C. F. de. Manejo da salinidade na agricultura: Estudo básico e aplicados. Fortaleza: INCT Sal, 2010. p.129-140.

EMBRAPA - Empresa Brasileira de Pesquisa Agropecuária Centro Nacional de Pesquisa de Solos. Sistema brasileiro de classificação de solos. 2.ed. Rio de Janeiro: EMBRAPA, 2006. 412p.

Feijão, A. R.; Silva, J. C. B.; Marques, E. C.; Prisco,J. T.; Gomes Filho, E. Efeito da nutrição de nitrato na tolerância de plantas de sorgo sudão à salinidade. Revista Ciência Agronômica, v.42, p.675-683, 2011. http://dx.doi.org/10.1590/S1806-66902011000300014

Ferreira, P. A.; Moura, R. F.; Santos, D. B.; Fontes, P. C. R.; Melo, R. F. Efeitos da lixiviação e salinidade da água sobre um solo salinizado cultivado com beterraba. Revista Brasileira de Engenharia Agrícola e Ambiental, v.10, p.570-578, 2006. http:// dx.doi.org/10.1590/S1415-43662006000300006

Gomes, S. O.; Pitombeira, J. B.; Neiva, J. N. M.; Cândido, M. J. D. Comportamento agronômico e composição químicobromatológico de cultivares de sorgo forrageiro no Estado do Ceará. Revista Ciência Agronômica, v.37, p.221-227, 2006.

Gurgel, G. C. S.; Santos, W. O.; Bezerra, F. G.; Barreto, H. B. F.; Lima, C. B. Produção de milho verde cultivado irrigado por gotejamento com água do efluente de aquicultura. Enciclopédia Biosfera, v.8, p.771, 2012

Magalhães, P. C.; Duraes, F.; Schaffert, R. E. Fisiologia da planta de sorgo. Sete Lagoas: EMBRAPA, 2000, 46p. Circular Técnica, 3.

Malavolta, E.; Vitti, G. C.; Oliveira, S. A. Avaliação do estado nutricional das plantas: princípios e aplicações. Piracicaba: Potafos, 1997. 319p.

Moraes, S. D.; Jobim, C. C.; Silva, M. S.; Marquardt, F. I. Produção e composição química de híbridos de sorgo e de milho para silagem. Revista Brasileira de Saúde e Produção Animal, v.14, p.624-634, 2013. http://dx.doi.org/10.1590/S1519-99402013000400002

Plett, D. C.; Moller, I. S. Na+ transport in glycophytic plants: What we know and would like to know. Plant, Cell and Environment. v.33, p.612-626, 2010. http://dx.doi.org/10.1111/j.13653040.2009.02086.x

Rebouças, A. C. Águas subterrâneas. In: Rebouças, A. C.; Braga, B.; Tundisi, J. G. Águas doces no Brasil: Capital ecológico, uso e conservação. São Paulo: Escrituras, 1999. p. 117-151.

Santos, D. B.; Ferreira, P. A.; Oliveira, F. G.; Batista, R. O.; Costa, A. C.; Cano, M. A. O. Produção e parâmetros fisiológicos do amendoim em função do estresse salino. Idesia, v.30, p.69-74. 2012. http:// dx.doi.org/10.4067/S0718-34292012000200009

Santos, R. D.; Pereira, L. G. R.; Neves, A. L. A.; Rodrigues, J. A. S.; Costa, C. T. F.; Oliveira, G. F. Agronomic characteristics of forage sorghum cultivars for silage production in the lower middle San Francisco Valley. Acta Scientiarum. Animal Sciences, v.35, p.13-19, 2013.

Simões, W. L.; Yuri, J. E.; Guimarães, M. J. M..; Santos, J. E.; Araújo, E. F. J. Beet cultivation with saline effluent from fish farming. Revista Brasileira de Engenharia Agrícola e Ambiental, v.20, p.62-66, 2016. http://dx.doi.org/10.1590/1807-1929/agriambi. v20n1p62-66

Vieira, M. R.; Lacerda, C. F. de; Cândido, M. J. D.; Carvalho, P. L.; Costa, R. N. T.; Tabosa, J. N. Produtividade e qualidade da forragem de sorgo irrigado com águas salinas. Revista Brasileira de Engenharia Agrícola e Ambiental, v.9, suplemento, p.42-46, 2005. 